\title{
ANALYSIS OF CONTEMPORARY TRENDS IN TOURIST MOVEMENT IN SARAJEVO CANTON WITH A SPECIFIC FOCUS ON THE TOURISTS FROM EU AND EUROPEAN COUNTRIES
}

\author{
Ranko Mirici ${ }^{29}$ \\ Nusret Drešković $\mathbf{c}^{30}$ \\ Boris Avdic ${ }^{31}$ \\ Edin Hrelja ${ }^{32}$
}

\begin{abstract}
Sarajevo Canton is by far the most visited tourism region in Bosnia and Herzegovina, considering that it has a share of over one third $(35,6 \%$ in 2016) of all registered tourists in Bosnia and Herzegovina. Sarajevo is a leader also in the context of percentage of foreign tourists (over $85 \%$ in 2016). In the paper, certain elements of contemporary tourism movement are taken for analysis from the aspect of quantitative indicators, by method of dynamic temporal comparison. Special focus was put on tourists from EU and other European countries. For the purpose of getting valid indicators of tourist movement trends, authors applied the analytical approach based on monthly quantitative data. Papers objective is to point out temporal dimension of these elements within the taken period, through analysis of monthly values of number of tourists and nights during the five-year tracking of specific trends, as well as to determine annual tourist distribution. Besides comparison of monthly and annual data about tourist movement, the paper is peculiarly oriented toward recognition of trend related to tourists from Europe.
\end{abstract}

Key words: tourism, Sarajevo Canton, tourist movement, tourism trends.

\section{INTRODUCTION}

Statistical monitoring of tourism and measuring its effects is very important for the public and private sector. The absence of quality and permanent statistical monitoring of tourism and its parameters means the inability to look at the objective effects, which is directly reflected in the potential measures and legal regulation of tourism-oriented policies. Tourist statistics mainly deals with data collection in the field of complex components of the tourist offer and tourist demand.

\footnotetext{
${ }^{29}$ Associate Professor, Department of Geography, Faculty of Science, University of Sarajevo, Sarajevo, Bosnia and Herzegovina.

${ }^{30}$ Associate Professor, Department of Geography, Faculty of Science, University of Sarajevo, Sarajevo, Bosnia and Herzegovina.

${ }^{31}$ Senior Assistant, Department of Geography, Faculty of Science, University of Sarajevo, Sarajevo, Bosnia and Herzegovina.

${ }^{32}$ Senior Assistant, Department of Geography, Faculty of Science, University of Sarajevo, Sarajevo, Bosnia and Herzegovina.
} 
In the earlier period in which tourism in the Sarajevo Canton was not recognized as a strategic direction of socioeconomic development, tourist supply statistics mainly referred to non-permanent monitoring of a smaller number of indicators (number of beds, rooms, places in complementary capacities, etc.) while he tourist demand was refered to statistics on number of arrivals and overnight stays. In recent years, thanks to the information and statistical innovations and the improvements of the methodology of tourism monitoring and its real effects in cantonal and municipal institutions (The Office of Information and Statistics of the Sarajevo Canton, Tourism Association of Sarajevo Canton, competent municipal and cantonal administration institutions), statistics of different aspects of tourist offer indicators and demand has reached qualitative and quantitative progress.

This step enabled the exact approach to study tourism trends that are necessary for the scientific and technical analysis of the position and role of the Sarajevo Canton in the tourism market in the national and regional frameworks. Based on the available data, the results of the scientific analysis enabled the recognition of changes in qualitative and quantitative indicators in the tourism market. Based on a critical analysis, enables the implementation of faster and more efficient adaptation, especially in the field of trends or changes, as a fundamental basis for taking more competitive market position. Monitoring of tourism trends is done through the analysis of numerical data on the movement of tourists in an area. In this sense, one can single out a series of indicators general, specific, temporal and structural, indicating the existing tendencies and most often correlated with some factors of social as well as natural character. Precisely, establishing such causal relationships is the main area of activity of geographers in the field of tourism. In this way they can recognize the potentials and disadvantages of a particular region in terms of tourism development, and accordingly make a significant contribution to creating a proper development policy or a set of necessary measures to improve the tourism industry's conditions. Inadequate or incomplete statistical data often make it difficult to reach an objective understanding of the state of tourism, so that the states and regions that recognize the development of this tertiary branch as an important strategic goal of the domestic economy must keep relevant statistics on arrivals, overnights and income from tourists, and have an insight in their structure. In the case of Sarajevo region, such data is collected at the cantonal level, and over the past few years with explosive growth in the influx of tourists, more attention is devoted to this segment. This paper uses data on the number of foreign tourists between 2012 and 2017, as well as the countries from which they came, with a special reference to European ones.

Sources and methods of data collection conducted by the Institute for Information Technologies and Statistics of the Sarajevo Canton are based on the data of tourism statistics that is collected through regular statistical survey of monthly statistics indicators of accommodation in tourism (tu-11 form). Reporting units are business entities (companies, crafts, co-operatives, institutions, associations, etc.) and their 
respectful units involved in providing accommodation services to tourists or only mediating in providing these services. The reports are compiled based on the records in guest books. What is to be noted is that the correction of the data is done on a monthly basis (http://zis.ks.gov.ba, accessed on 11th December 2017)

In the monthly reports on tourism capacities, tourists and overnight stays in the Sarajevo Canton, in the observed period and according to the mentioned methodology, the following indicators are monitored and statistically processed:

- number of business units, number of available capacities, number of beds (by municipalities and the Sarajevo Canton);

- number of tourist arrivals - domestic and foreign (by municipalities and the Sarajevo Canton);

- number of overnight stays - domestic and foreign (the municipalities and the Sarajevo Canton);

- arrivals and overnight stays by different types of a facility (at the cantonal level, for domestic and foreign tourists);

- hotels and similar accommodation, resorts and similar facilities for short breaks, camps and the camping areas, and other accommodation;

- arrivals and overnights of foreign tourists by country of residence - at cantonal level.

In this respect, the Institute for Information Technologies and Statistics of the Sarajevo Canton, methodologically uses the following definition: Foreign tourists are persons who do not have a permanent residence in Bosnia and Herzegovina and who spend at least one night in a hotel or other accommodation facility for guests' accommodation (http://zis.ks.gov.ba, accessed on 11th December 2017).

\section{GENERAL TOURISM TRENDS IN SARAJEVO CANTON}

Sarajevo Canton is one of the 17 tourism regions in Bosnia and Herzegovina (Mirić et al., 2017). This type of tourism regionalization was carried out on the basis of the administrative structure of the national (state) territory as well as the planning documents. This type of territorial organization of tourism in an area is considered suitable for statistical monitoring of relevant trends, as well as process management in the tourism industry. Based on the comparison of all 17 regions, it can be said that Sarajevo Canton is by far the most attractive area for tourists in Bosnia and Herzegovina, since in 2014 more than one third (35.6\%) of the total number of tourists in this country visited Sarajevo. This especially relates to foreign tourists, where among those registered in Sarajevo Canton, $84 \%$ are foreigners. Only slightly less than half of the total number of foreign tourists $(47 \%)$ who visited Bosnia and Herzegovina stayed in Sarajevo Canton. Sarajevo is also among the regions with the fastest growth of tourists. Between 2005 and 2014 this number increased by 2.5 times. Only three regions (West Herzegovina, Livno and Trebinje) had a stronger growth over the same 
period, but are areas with a very low base, that is, the regions whose tourism development is at its initial phase. However, it is necessary to point out to the trend of decreasing the average number of overnight stays by tourists in Sarajevo (less than two nights per tourists in 2014), which can be interpreted also through the lack of different tourist activities (greater offer) that would keep visitors longer.

Sarajevo Canton is located in the central part of Bosnia and Herzegovina, with a total of $1277 \mathrm{~km}^{2}$ and has about 414.000 inhabitants according to the latest census of 2013 . It represents the most populated part of the country, and among other cantons in the Federation of Bosnia and Herzegovina, it is the second most populated canton (after Tuzla Canton). It is territorially divided into nine municipalities, of which four (Stari Grad, Centar, Novo Sarajevo and Novi Grad) make the City of Sarajevo, the capital of Bosnia and Herzegovina. The Ilidža and Vogošća municipalities have a typical suburban character, while Hadžići, Ilijaš and Trnovo have quite small urban centers, dominated by rural and natural landscapes. The majority of tourist attractions and the largest concentration of tourists is linked to the city of Sarajevo, primarily along the old part of town. The newer (western) parts of Sarajevo have primarily a housing function and are not of a great importance for the tourism industry. In the suburban area, Ilidža represents an important tourist location, primarily due to the great concentration of modern hotels in the area, but also the specific combination of the natural and culturalhistorical heritage. The outer ring around Sarajevo is characterized by a spacious forest areas and other types of natural mountain environment, which is suitable for the development of alternative forms of tourism.

Cultural-historical motives prevail in the tourist offer of the Sarajevo region (Nurković et al., 2006). Their greatest concentration lies in the Old Town area, which is the historical center of urbanization of Sarajevo. The Oriental Town Square on Baščaršija represents a historical center, which is followed by the functional center of the city, dominated by the structures of the Central European architecture from the AustroHungarian period (Žunić, 2014). This blend of eastern and western style gives Sarajevo a visual characteristic of a multicultural and multiconfessional city. This fact builds the tourist image of Sarajevo as one of the most specific cultural and historical destinations in the world. Sarajevo is also an Olympic city because it hosted the Winter Olympics in 1984, but in the modern tourist offer this segment is not sufficiently emphasized. Greater interest among tourists causes the more recent history, which is marked by a long siege of the city during the war between 1992 and 1995. Natural attractions in the vicinity of Sarajevo make an important addition to the basic tourist image of the city. This primarily refers to the mountains Bjelašnica, Igman, Treskavica, etc., as well as the protected areas of Vrelo Bosne, Skakavac, Bijambare and Trebević. 


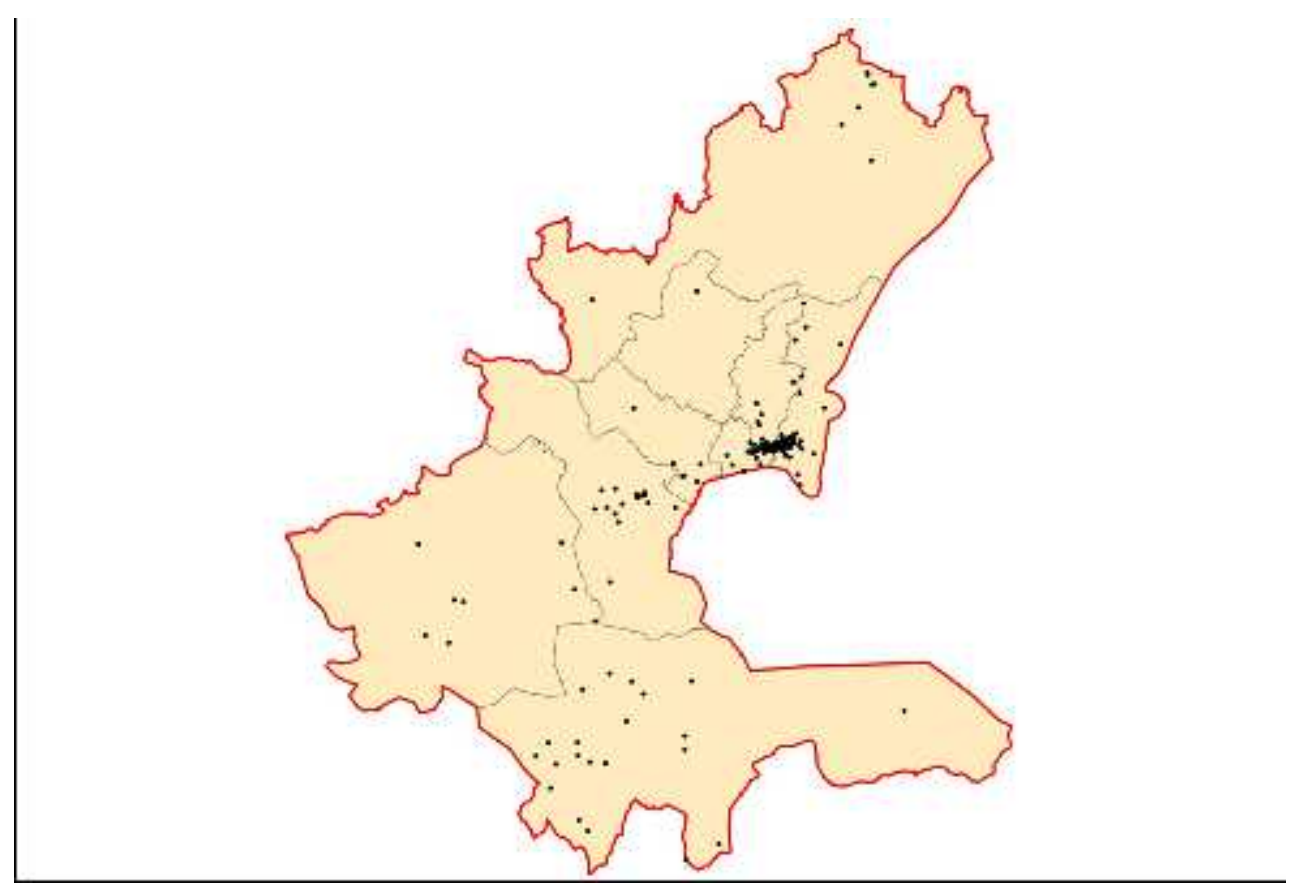

Fig. 1. Territorial distribution of tourism attractions in the Sarajevo Canton

Affirmation and promotion of the mentioned tourist motives has led to the rapid and continuous growth of the tourism industry in Sarajevo after the war. The available statistics show that between 2002 and 2016 the number of registered tourists increased six times (from 80.271 to 482.494). The figure of 100.000 tourists for the first time after the war was recorded in 2004, 200.000 was achieved in 2010, 300.000 already in 2013, and 2016 was the first in which the total number of tourists in the Canton Sarajevo exceeded the figure of 400.000. In the analysis of this general growth trend is evident the slowdown of this pace in the time of the global economic crisis at the end of the first decade of this century. Furthermore, the decline in tourist traffic was recorded twice in the observed period - 2003 and 2014, as a result of the worsening of the security situation (first in the global and then at the local level). It is interesting that in the observed period, the number of domestic tourists stagnates or slightly increases, while the international tourist traffic has achieved exceptionally rapid progress.

\section{TERRITORIAL DISTRIBUTION OF TOURISTS}

When it comes to the territorial distribution of tourists in Sarajevo Canton, then the interpretation of statistical data on registered visitors of accommodation facilities are only partially relevant, since the existing hotels are not necessarily in the area with the biggest tourist attractiveness. Thus, for example, the largest number of tourists (over 150.000) were registered in the suburban municipality of Ilidža. Due to the spatial reasons and close proximity to the airport, some exceptionally large and modern hotels 
have been built in this area, and it is where almost a third of all tourist stays are registered in Sarajevo (Hrelja, 2012). However, this does not make Ilidža the top tourist destination in this area.

As already mentioned, the subject of interest of the vast majority of visitors to Sarajevo is the old part of the city and the municipality of Stari Grad with the largest number of registered tourists in the city of Sarajevo (around 100.000 in 2016). This number would certainly be significantly higher if there was more space available for construction, thus there would be more accommodation capacities, and consequently the accessibility would be higher. A similar example represents the municipality of Centar, which has about 65.000 registered tourists. The remaining urban municipalities (Novo Sarajevo and Novi Grad) have between 30.000 and 40.000 visitors, having in mind that these are densely populated parts of Sarajevo. The municipalities of Trnovo, Vogošća and especially Hadžići have a relatively small number of registered tourists, while in Ilijaš there are no capacities at all.

\section{COMPOSITION OF TOURISTS BY COUNTRY}

Most tourists in Sarajevo have traditionally consisted of visitors from neighboring countries, but the situation in recent decades changed significantly. While tourists from Serbia, Croatia and Slovenia remained important clients, meanwhile, the rapid influx of visitors from other parts of Europe and the world led to major changes in the direction of the development of tourism industry in the capital of Bosnia and Herzegovina. Not so long ago, the tourists from non-European countries were rare in Sarajevo, and today they have a significant share of $29.5 \%$ in the overall structure of the foreign visitors in Sarajevo. Over the past few years, there has been a significant increase in the number of tourists from the Arab states (Kuwait, United Arab Emirates, Qatar, Oman and others). Still, over $70 \%$ of visitors to Sarajevo come from Europe, and this paper focuses on this segment of tourist traffic. Tourists from the European Union make up $44.1 \%$ of registered foreign tourists, while the recorded percentage of tourists from other European countries in the last five years is $26.3 \%$. The same goes largely to tourists from Turkey and Serbia.

According to the annual average for the period 2013-2016, tourists from Turkey represent the largest group among all foreign tourists. As of 2013, around 48.000 of tourists from turkey come to Sarajevo annually. In the context of this paper, the same are referred to as European tourists due to fact that the Republic of Turkey has been classified by the UNWTO as the Eastern European Mediterranean region. Among other countries contributing to the Sarajevo region on average with more than 10.000 tourists per year are the three former Yugoslav countries - Croatia (37.000), Slovenia (18.000) and Serbia (13.000). The only other European country whose tourists were recorded with the average number of more than 10.000, is Germany (11.000). There is also a relatively significant number of tourists from other major European Union countries - 
Italy, Austria, Poland, the United Kingdom, France and Spain (over 5000 tourists a year).

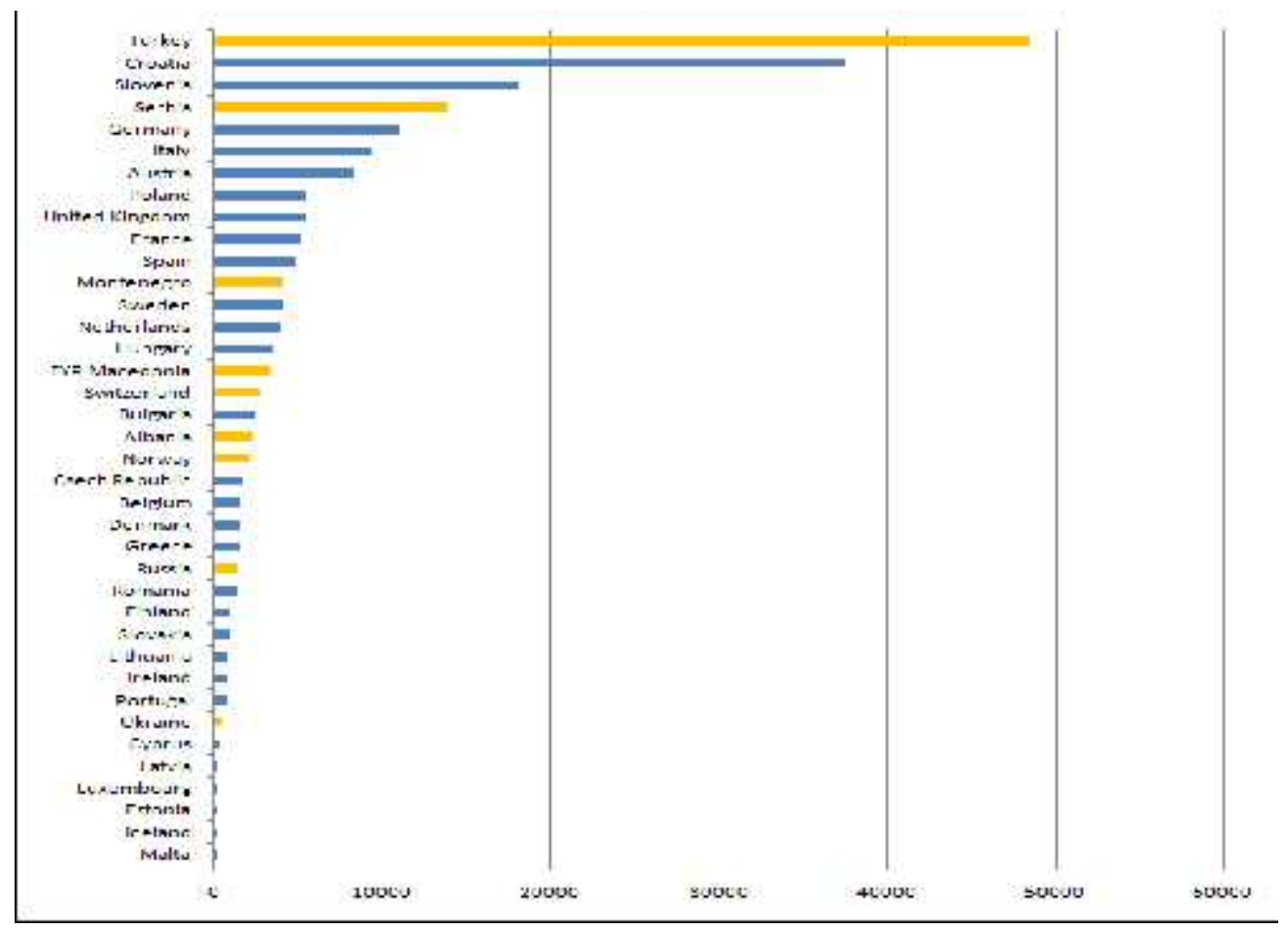

Fig. 2. Average annual number of tourists from European countries in Sarajevo Canton for the period of 2013-2017 Source: http://zis.ks.gov.ba, accessed on 11th December 2017

It is very interesting to observe the stated period (2013 - 2016) in the context of tourist traffic trends structured in different European countries. Thus it it is evident that in spite of the general increase in the number of tourists, there is a continuous declining trend when it comes to the countries of the region. There is a particularly negative data for Croatia showing more than $20 \%$ of the decline of tourists from this country in comparison to the 2013. There is also a decline in the number of Slovenian tourists by $17 \%$, and the Serbian by $2 \%$. These data clearly confirms the already noted fact that Sarajevo is experiencing a transformation from a regional tourist center into the continental and the global center. This is evidenced by the steady increase in tourist arrivals from the large and developed European countries. In relative terms, the highest growth is achieved by countries whose tourists still do not have the status of statistically significant clients in Sarajevo. These are, for example, Iceland, Cyprus, Luxembourg, Ireland and Switzerland, with a growth of over 50\%, with the latter having a more pronounced tendency to gain a greater significance for the development of Sarajevo tourism in the future. In absolute numbers, the largest growth is realized by Turkish and German tourists, and it should be pointed out that tourists from Sweden and the 
Netherlands are becoming more and more active, with a growth rate of over $30 \%$ between 2013 and 2016.

\section{SEASONAL DISPARITIES}

Seasonal tourism activity also represents an important segment of the general tourist profile of a destination. Given the rather pronounced oscillations in this regard, neither the Sarajevo Canton case is an exception in this context. For example, certain months in Sarajevo can have up to four times the number of registered tourists compared to the months with the lowest tourist turnover. The monthly average for the period from 2013 to 2016 was taken for analysis of this dimension too. In this way it was found that the most active periods in the arrival of foreign tourists late spring and late summer, which coincides with periods of the most favorable weather conditions for the development of tourism. August is a record month with nearly 40.000 registered foreign tourists, which is the result of another factor - the Sarajevo Film Festival, the largest event of this kind in this part of Europe. The high level of tourist visits extends also in September, as well as in May and June. In all these months more than 30.000 foreign tourists are registered. In July, the number of tourists drops, primarily due to the fact that global and regional tourist movements are primarily geared towards seaside destinations. In the Sarajevo canton, every month, from November to February, records a significantly lower level of tourist traffic (less than 15.000 tourists), indicating insufficient attention to the winter tourist offer of this once Olympic city, as well as to the frequent problem of air pollution in the Sarajevo valley in these months.

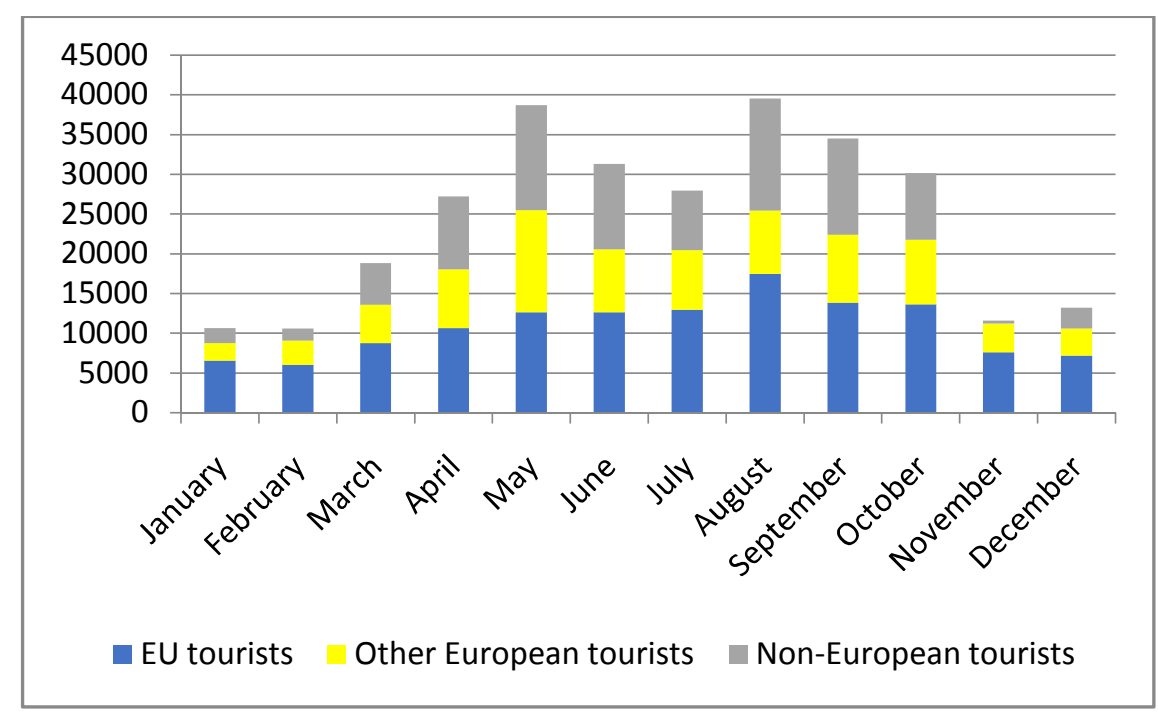

Fig. 2. Average annual number of tourists from European countries i

Sarajevo Canton for the period of 2013-2017

Source: http://zis.ks.gov.ba, accessed on 11th December 2017 
From the analysis of the structure of tourists in Sarajevo Canton by months it appears that, unlike the visitors from the European Union countries who prefer August as the time of the Sarajevo Film Festival, and the early fall, the visits of Turkish and Arab tourists are significantly more connected with the spring period. Particularly noticeable are large seasonal variations when it comes to the number of tourists from Turkey. The average number of Turkish visitors for the period 2013-2016. in May is much higher than in other months, exceeding the figure of 9000 . In the winter months, this number is drastically smaller, up to 20 times. On the other hand, it can be said that the situation with tourists from neighboring Croatia is totally opposite (Glamuzina, 2009). A relatively large number of tourists from this country are registered in December and January (over 3000) and is only slightly higher in October and March. In the case of Slovenian tourists, there is a clear preference for the spring and autumn months, especially those of April and October, when more than 2000 visitors from this country are registered. Tourists from Serbia show a trend of relative seasonal consistency unlike the Germans, who, to a greater extent, visit Sarajevo during the warmer period of the year.

\section{CONCLUSION}

Sarajevo Canton, or Sarajevo Region, is the bearer of tourism development of Bosnia and Herzegovina, and Sarajevo as the city becomes more recognizable tourist destination in the European and global terms. This fact triggers various processes that lead to the transformation of Sarajevo and its environment in various aspects - spatial, economic, cultural, ecological, infrastructural, etc. At the same time a certain transformation of the tourist offer, as well as the profile of tourists visiting this destination occurs. These changes are best evidenced by monitoring the visitor structure and recent trends in this regard. In general it can be said that Sarajevo becomes less and less oriented towards domestic tourists and those from neighboring countries, and that the focus of tourism development is put to tourists from major generating markets, which are located on the European continent, but also outside. All these changes have a very dynamic character, and require the development of a planning approach in the creation of tourism policy, so that the uncontrolled action would not lead to unwanted contradictions in future trends. In this respect, the European Union countries, besides being an important space for attracting tourists, can also serve as an example of an adequate tourism management, in which the Sarajevo region could also fit.

\section{REFERENCES}

1. Glamuzina, N. (2009): Uloga Hrvatske u valorizaciji turističkih potencijala Bosne

$i$ Hercegovine. Zbornik radova Drugoga kongresa geografa Bosne i Hercegovine. Geografsko društvo u Federaciji Bosne i Hercegovine, Sarajevo. 
2. Hrelja, E. (2012): Prostorna analiza lokacije hotela u Kantonu Sarajevo kao osnova turistickkog razvoja, Edukacija iz turizma i zaštite životne sredine kao preduvjet turističkog regionalnog i prostornog planiranja, Geografsko društvo u Federaciji Bosne i Hercegovine, Sarajevo.

3. Mirić, R., Drešković, N., Avdić, B., Hrelja, E. (2017): Concepts of tourism regionalization and analysis of contemporary trends of tourist movement in Bosnia and Herzegovina. Proceedings Book - 2nd International Tourism and Hospitality Management Conference - ITHMC 2016.

4. Nurković, S., Mirić, R., Drešković, N., Jahić, H. (2006): Regionalni aspekti turističkih potencijala Kantona Sarajevo - klasifikacija i valorizacija. Međunarodni naučni simpozij Turizam kao faktor regionalnog razvoja - Zbornik radova. Univerzitet u Tuzli, Tuzla.

5. Žunić, L. (2014): Turistički resursi i potencijali urbane jezgre Sarajeva. Zbornik radova Trećeg kongresa geografa Bosne i Hercegovine. Geografsko društvo u Federaciji Bosne i Hercegovine, Sarajevo.

6. http://zis.ks.gov.ba (11th December 2017) 